\title{
Biliary Tract in Trident, an Anatomical Variation Between the Cystic Duct and its Union to the Common Hepatic Duct. A Rare Case Report
}

\author{
Tracto Biliar en Tridente, una Variación Anatómica Entre el Conducto \\ Cístico y su Unión al Conducto Hepático Común. Un Caso Raro
}

\author{
Oscar Plaza $^{1} \&$ Freddy Moreno ${ }^{2}$
}

PLAZA, O. \& MORENO, F. Biliary tract in trident, an anatomical variation between the cystic duct and its union to the common hepatic duct. A rare case report. Int. J. Morphol. 37(1):308-310, 2019.

SUMMARY: Given that the gallbladder and the biliary tract are subject to multiple anatomical variants, detailed knowledge of embryology and its anatomical variants is essential for the recognition of the surgical field when the gallbladder is removed laparoscopically or by laparotomy, even when radiology procedures are performed. During a necropsy procedure, when performing the dissection of the bile duct is a rare anatomical variant of the bile duct, in this case the cystic duct joins at the confluence of the right and left hepatic ducts giving an appearance of trident. This rare anatomical variant in the formation of common bile duct is found during the exploration of the bile duct during a necropsy procedure, it is clear that the wrong ligation of a common hepatic duct can cause a great morbi-mortality in the postsurgical of biliary surgery. This rare anatomical variant not previously described is put in consideration to the scientific community. Anatomical variants of the biliary tract are associated with high rates of morbidity and mortality, causing serious bile duct injuries. Only the surgical skill of the surgeon and his open mind to the possibilities of abnormalities make the performance of cholecystectomy a safe procedure.

KEY WORDS: Anatomical variants; Liver; Gallbladder; Extrahepatic bile duct; Hepatic duct; Cholecystectomy.

\section{INTRODUCTION}

The presence of anatomical variants in an intraoperative challenge for general surgeons and/or laparoscopists since these alterations in the architecture of the bile duct are not uncommon, therefore increases the chances of biliary lesions during surgery (Puente \& Bannura, 1983; Vennarecci et al., 2014). The knowledge of the embryology of the digestive system together with the previous dissections in corpses in medical schools, will generate skills in future surgeons who, with surgical training; will acquire the skills that will modify the course of the chances of success minimizing and the risk of injury to the biliary tract (Fullum et al., 2013; Davis et al., 2014; Mahadevan, 2014).

During embryonic development, the intra and extrahepatic bile duct is formed from the primitive intestine. The liver, gallbladder and bile ducts (bile ducts, common hepatic duct, common bile duct and cystic duct) originate from the bud or hepatic diverticulum, initially a thickening and then a ventral evagination of the endoderm of the anterior primitive intestine which, at beginning of the fourth week, it extends to the transverse septum of the future diaphragm. This hepatic diverticulum, when enlarged, divides into a cranial part or hepatic primordium that will differentiate in the liver, and a caudal part or biliary primordium that will give rise to the gallbladder. In turn, the stem of the hepatic diverticulum forms the hepatic duct and the stem of the diverticulum of the biliary primordium forms the cystic duct, which together are connected to the duodenum through the common bile duct (Moore et al., 2015). However, it is still unknown how the intrahepatic duct network connects with the extrahepatic ducts (Raynaud et al., 2011).

In this morphogenetic process, the expression of fibroblast growth factor (FGF-2) has been identified from cardiac cells and morphogenic bone protein (BMP-2, BMP4 and BMP-7) from the transverse septum, which induce to

\footnotetext{
${ }^{1}$ Instituto Nacional de Medicina legal y Ciencias Forenses (Cali, Colombia); Facultad de Medicina, Universidad Santiago de Cali Cali, Colombia.

${ }^{2}$ Departamento de Ciencias Básicas de la Salud, Facultad de Ciencias de la Salud Pontificia Universidad Javeriana Cali, Colombia.
} 
the endoderm for the initial formation of the hepatic diverticulum. To the extent that epithelial-mesodermal relationships are established between the endoderm and the underlying mesoderm, the parenchyma of the liver and the tunicae of the gallbladder are formed, while the hepatic and biliary stems are recanalized-after the stimulation of different paracrine factors and autocrine drugs such as estrogen, insulin growth factor 1 (IGF-1), interleukin 6 (IL-6) and vascular endothelial growth factor (VEGF) - to form the different ducts that make up the bile duct (Strazzabosco \& Fabris, 2012). This process occurs between the fifth and twelfth week of development, the last time that bile enters the gastrointestinal tract through the duodenum, causing a dark green coloration to meconium (Sadler, 2012; Carlson, 2014). Likewise, failures in the expression of HNF6, HNF$1 \mathrm{~b}$ or Foxf1 result in alterations in the development of the gallbladder and the common bile duct. In this way, the morphogenesis of the bile duct is susceptible to presenting anatomical variations that may be habitual but clinically not significant, resulting in reports of accessory hepatic ducts and duplications of the gallbladder (Sadler).

\section{CASE REPORT}

The Colombian legislation is clear when indicating that, when performing a medical-legal necropsy procedure, it must be complete and all organs must be checked, which includes the bile duct. In this case, it is a male individual who dies from unnatural causes; when exploring the bile duct in search of stones, it is observed that the cystic duct empties between the confluence of the right and left hepatic ducts, giving the appearance of a "trident" (Fig. 1).

\section{DISCUSSION}

The right and left hepatic ducts come from their respective segments in the liver and join in the porta hepatis ('the doorway to the liver') to form the common hepatic duct, to which the cystic duct is later attached to form the common bile duct or common bile duct. This disposition was described by Couinaud, who affirms that the biliary tract is formed by hepatic ducts that follow a modal disposition identical to that of the portal vein (Chaib et al., 2014). The possible anatomical variations of the cystic duct include alterations in its length, in the union to the right and left hepatic ducts, accessory ducts and absence of cystic duct (Ellis, 2011), which have been widely discussed in different studies and reports (Lamah et al., 2001; Kostov \& Kobakov, 2011; Sarawagi et al., 2016).

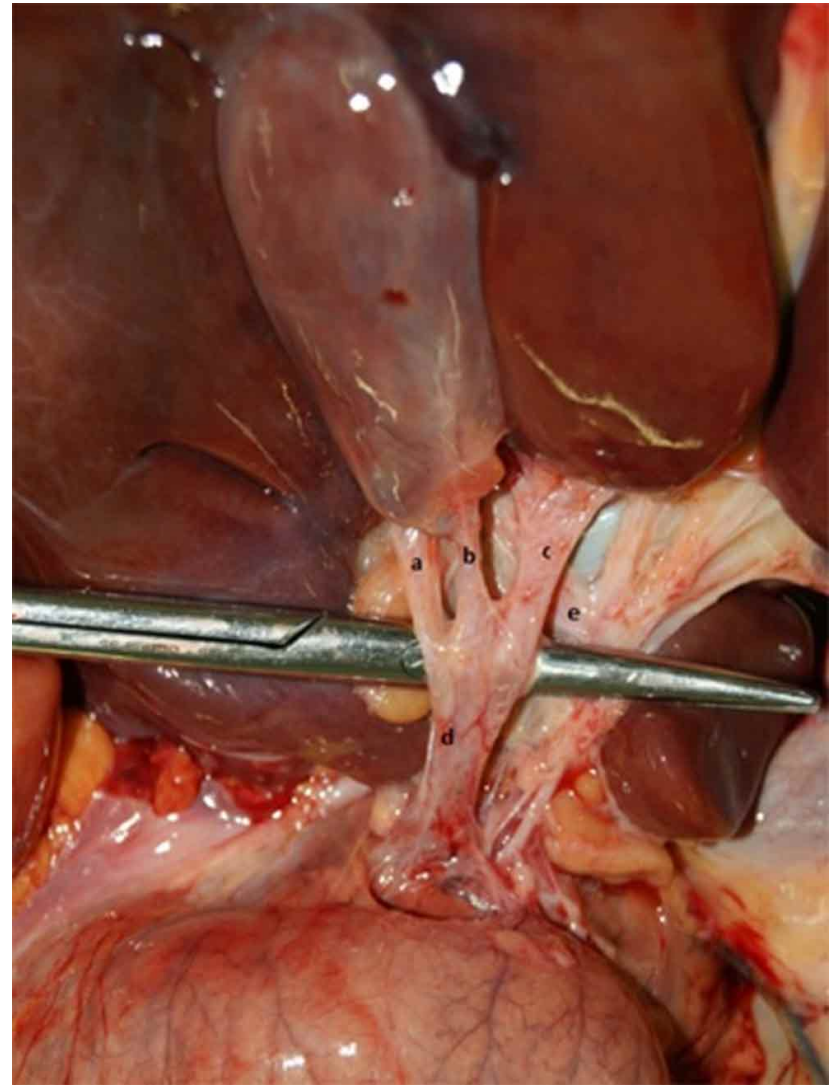

Fig. 1. a. Right main hepatic duct; b. Cystic duct; c. Left hepatic duct; d. Bile duct; e. Cystic artery.

In conclusion, the anatomical variants of the bile duct most frequently found are related to the right and left bile ducts and the draining hepatic segments.When reviewing the anatomy books and the available specialized bibliography, related to the hepatobiliary pathway and its anatomical variations, this anatomical presentation was not reported, so it is available to readers and especially to laparoscopic surgeons and radiologists in order to reduce the procedural risks in the bile duct.

PLAZA, O. \& MORENO, F. Tracto biliar en tridente, una variación anatómica entre el conducto cístico y su unión al conducto hepático común. Un caso raro. Int. J. Morphol., 37(1):308-310, 2019.

RESUMEN: Dado que la vesícula biliar y el tracto biliar están sujetos a múltiples variantes anatómicas, el conocimiento detallado de la embriología y sus variantes anatómicas es esencial para el reconocimiento del campo quirúrgico cuando la vesícula biliar se extirpa laparoscópicamente o por laparotomía, incluso cuando se realizan procedimientos de radiología. Durante un procedimiento de necropsia, se realiza la disección del conducto biliar y se observa una variante anatómica inusual del conducto biliar; en este caso, el conducto cístico se une a la confluencia de los 
conductos hepáticos derecho e izquierdo dando una apariencia de tridente. Esta rara variante anatómica en la formación del conducto biliar común puede causar una gran morbimortalidad en la cirugía biliar asociado a una ligadura incorrecta. Esta extraña variante anatómica no descrita anteriormente se reporta a la comunidad científica, debido a que las variantes anatómicas del tracto biliar se asocian con altas tasas de morbilidad y mortalidad, al causar lesiones graves en el conducto biliar. Solo la habilidad quirúrgica del cirujano y su mente abierta a las posibilidades de variaciones anatómicas hacen que la realización de la colecistectomía sea un procedimiento seguro.

PALABRAS CLAVE: Variantes anatómicas; Hígado; Vesícula biliar; Conducto biliar extrahepático; Conducto hepático; Colecistectomía.

\section{REFERENCES}

Carlson, B. M. Human Embryology and Developmental Biology. 5a ed. New York, Elsevier, 2014.

Chaib, E.; Kanas, A. F.; Galvão, F. H. \& D'Albuquerque, L. A. Bile duct confluence: anatomic variations and its classification. Surg. Radiol. Anat., 36(2):105-9, 2014.

Davis, C. R.; Toll, E. C.; Bates, A. S.; Cole, M. D. \& Smith, F. C. Surgical and procedural skills training at medical school - a national review. Int. J. Surg., 12(8):877-82, 2014.

Ellis, H. Anatomy of the gallbladder and bile ducts. Surgery, 29(12):593-6, 2011.

Fullum, T. M.; Downing, S. R.; Ortega, G.; Chang, D. C.; Oyetunji, T. A.; Van-Kirk, K.; Tran, D. D.; Woods, I.; Cornwell, E. E. \& Turner, P. L. Is laparoscopy a risk factor for bile duct injury during cholecystectomy? JSLS, 17(3):365-70, 2013.

Kostov, D. V. \& Kobakov, G. L. Six rare biliary tract anatomic variations: implications for liver surgery. Eurasian J. Med., 43(2):67-72, 2011.

Lamah, M.; Karanjia, N. D. \& Dickson, G. H. Anatomical variations of the extrahepatic biliary tree: review of the world literature. Clin. Anat., 14(3):167-72, 2001

Mahadevan, V. Anatomy of the gallbladder and bile ducts. Surgery, 8:1-5, 2014.

Moore, K. L.; Persaud, T. V. N. \& Torchia, M. G. Clinical Embriology. $10^{\text {th }}$ ed. New York, Elsevier, 2015.

Puente, S. G. \& Bannura, G. C. Radiological anatomy of the biliary tract: variations and congenital abnormalities. World J. Surg., 7(2):271-6, 1983.

Raynaud, P.; Carpentier, R.; Antoniou, A. \& Lemaigre, F. P. Biliary differentiation and bile duct morphogenesis in development and disease. Int. J. Biochem. Cell Biol., 43(2):245-56, 2011.

Sadler, T. W. Medical Embriology. 11 ${ }^{\text {th }}$ ed. London, Wolters Kluwer, 2012.

Sarawagi, R.; Sundar, S.; Raghuvanshi, S.; Gupta, S. K. \& Jayaraman, G. Common and uncommon anatomical variants of intrahepatic bile ducts in magnetic resonance cholangiopancreatography and its clinical implication. Pol. J. Radiol., 81:250-5, 2016.

Strazzabosco, M. \& Fabris, L. Development of the bile ducts: essentials for the clinical hepatologist. J. Hepatol., 56(5):1159-70, 2012.

Vennarecci, G.; Levi Sandri, G. B.; Colace, L. \& Ettorre, G. M. Unrecognized right posterior biliary duct: an intra-operative finding. Surg. Radiol. Anat., 36(6):617-8, 2014.
Corresponding author:

Dr. Oscar Plaza

Facultad de Medicina

Universidad Santiago de Cali

Cali

COLOMBIA

Email: oscarplazap33@hotmail.com

Received: 18-07-2018

Accepted: 12-12-2018 